\title{
Online Tourist Information in the Largest Polish Cities
}

\author{
Michał Rogoż \\ ORCID 0000-0002-8041-0610 \\ Institute of Information Sciences, \\ Pedagogical University of Cracow, Poland
}

\begin{abstract}
Purpose/Thesis: This paper analyzes selected tourism websites for the largest cities in Poland. The paper answers following research questions: are the different websites designed to provide the tourists the relevant information?; do local conditions shape the content provided on these websites?; are these websites multilingual?; do they suggest possible itineraries?; how do they develop?

Approach/Methods: The article uses comparative quantitative and qualitative analysis to study the information systems employed by the websites of the largest Polish cities: Warsaw, Krakow, Lodz, Wroclaw, Poznan and Gdansk. These cities are popular tourist destinations; each has an information system, reflecting the specific tourist services they offer.

Results and conclusions: The organization scheme for each website is different, despite the fact that they were all designed for related organizational entities gathered in the structure of Polish Tourism Organization. Each site has a different design and appearance; different resources were dedicated to each. They are more varied than the websites of the analogous organizations operating in countries such as Germany, the Netherlands, and Sweden. The specificity of the region has more of an impact on the content offered to the user. In recent years, more flat websites, imitating the paper guides, were gradually replaced by multimedia platforms enabling various interactions with more dynamic content. Originality/Value: To the best of the author's knowledge, the research presented in the paper is the first attempt to characterize and compare tourist information websites of the six largest cities in Poland.
\end{abstract}

\section{Keywords}

Comparative analysis. Tourist information. Web content. Website structure.

Received: 2 October 2019. Reviewed: 21 October 2019. Revised: 15 December 2019. Accepted:18 December 2019.

\section{Introduction}

Web services have become an important instrument for information dissemination and promotion in the tourism industry. Information published online is needed at all stages of travel: in the planning phase, in which online resources and various booking websites are used, on-site during the tour (increasingly available at digital stationary terminals, so-called info-kiosks), and finally at the stage of evaluation and sharing the account of the tour (Meyer \& Pawlicz, 2010, 74-76).

Furthermore, the development of wireless networks enables the tourist to access information sources while traveling with the use of devices such as netbooks, tablets or smart phones. 
Tourism websites publish information produced by particular organization such as offices of local governments, public and private agencies, regional media, non-governmental organizations, travel agencies, schools, museums, accommodation facilities and other service providers which prioritize territorial marketing.

The development of the World Wide Web has also influenced the tourist information services, allowing the transmission of the traditional marketing offer to an online and interactive environment. Internet communication makes it possible to respond instantly to changing market conditions. The maintenance costs are low, as Internet communication eliminates middlemen from the process (Reformat, 2015). The development of network services has contributed to the emergence of a new type of tourist: one, who is knowledgeable and willing to participate in experiences with a special orientation; who seeks out timely and financially advantageous offers (Goworecki, 2003, 336-337).

Tourism websites quickly developed for large cities, which have always been centers where tourism and business focused. Cities are specific tourist destinations. The nature of the accumulated tourist attractions favors the development of cultural tourism focused on historical sites, memorials and other architecture reflecting the unique history of the place (including landmarks), museums and other cultural and entertainment facilities, as well as on participation in various events and festivals. Business tourism, conferences and fairs are becoming an important part of tourism. Large urban areas used for recreation and rest (parks, green spaces and various sports facilities) are an important element of the tourist offer. Worthy of mention is the increasingly wide-spread phenomenon of shopping vacations undertaken to purchase specific local items, or enjoy services available only in larger agglomerations (Paliś, 2017). Local tourist information typically takes into account every element of infrastructure which might facilitate optimizing the tourist experience: accommodation, catering, commerce, communication, banking system, and various services (Kęprowska, 2012).

\section{The largest Polish cities - tourism specifics, research problems}

This study compares the content and structure of tourism websites offered by the six largest Polish cities (Warsaw, Krakow, Lodz, Wroclaw, Poznan and Gdansk), bearing in mind that it will prioritize the appeal and cultural specificity of the studied sites. The paper will answer following questions:

(a) Are the different websites designed to provide the tourists the relevant information?

(b) Do local conditions shape the content provided on these websites?

(c) Are these websites multilingual?

(d) Do they suggest possible itineraries?

(e) How do they develop?

The article uses comparative quantitative and qualitative analysis to study the content and structure of the websites. These cities are popular tourist destinations, and for each of them there are several tourism websites, offering specific tourist information services. The selected Polish cities are all important hubs near highways, with their own airports and train stations allowing international travel ${ }^{1}$. They are also administrative centers at the

${ }^{1}$ It is worth noting that Gdansk is additionally an international harbor. 
highest level (the capital of the state, regional capitals). Tourism plays an important role in the economy of all these cities. Taking the local accommodation facilities as an indicator, it can be stated that tourism is the most important in the economy of Krakow, and very important for Warsaw, Wroclaw, Poznan and Gdansk, and it is slightly less significant in the case of Lodz (Ostrowska 2010). The biggest Polish cities enjoy international prestige: Krakow and Wroclaw have been recognized as European Capitals of Culture, while other cities appeared on various lists promoting specific tourist destinations ${ }^{2}$. Krakow, Warsaw and Wroclaw are home to objects inscribed on the UNESCO World Heritage Sites list. All these cities are featured on the President's list of Historical Monuments identifying monuments of special significance for the culture of Poland ${ }^{3}$. Additionally, Krakow, Wroclaw and Gdansk are convenient bases for more wide-ranging explorations of the most attractive tourist regions in Poland: Carpathians, Pomerania and the Sudetenland. There are national parks near Warsaw, Krakow, and Poznan. Lodz is a center of industrial tourism, associated with the local industrial heritage of the city's textile industry plants, and has become more popular in recent years.

\section{Tourism websites}

In Poland, an online tourist information systems developed gradually, embracing the agendas associated in the Polish Tourist Organization ${ }^{4}$. They refer to the administrative units at all levels (provinces, counties, municipalities) and to the specific regions central to the identity of a given regional product and the intensification of tourist traffic around it (Kruczek \& Walas, 2004, 171-179). Currently, the Polish Tourism Organization's website (polska.travel) contains concise but relevant characteristics of the largest Polish cities with photographs and, in some cases, short advertising spots, or with links to cameras showing current images.

Another way to find information about Polish cities' offer for tourists is to use online dedicated web services. These websites represent the local self-government authorities and are multi-aspect platforms publishing content targeting not only tourists, but also residents or investors, such as information about taxes and infrastructure, activities of public authorities and local administration. These websites often devote a separate domain to tourism. The number of these domains of these sections might reflect the importance of tourism to a given city.

Table 1 presents selected tourism websites for the six largest cities in Poland, but does not include several private initiatives presenting national and international online digital versions of city guides. We should mention Jasna strona miasta, a website administered

\footnotetext{
${ }^{2}$ In 2018, Wroclaw was chosen as the best tourist destination in Europe, and a year earlier Gdansk was third in that poll. A year later, Poznan took the fifth place. Electronic document, See: https://www. europeanbestdestinations.com/. In many lists published by prestigious websites (e.g. Tripadvisor, Zoover) and magazines (Which), Krakow also ranked high.

${ }^{3}$ Objects listed by the President of Poland as Historical Monuments, See: https://www.prezydent.pl/ aktualnosci/pomniki-historii/obiekty-wpisane-na-liste-pomnikow-historii

${ }^{4}$ It is a government organization established pursuant to the Law of 25 June 1999 on the Polish Tourist Organization.
} 
by the British company Lifeboat Ltd. (Warsaw, Krakow, Wroclaw, Poznan, and Gdansk) a series of regional and city guides entitled In Your Pocket Essential City Guides (Warsaw, Krakow, Lodz, Wroclaw, Poznan, and Gdansk $)^{6}$, the Hungarian Pocket Guide application (Warsaw, Krakow) showing detailed tour routes for Android and iOS, as well as the English-language series entitled Arrival Guides (Poznan and Warsaw also have Polish language versions) which is a part of the Lonely Planet guide series ${ }^{7}$. We should also remember the information systems supporting the tourist news services (tripadvisor.com) or booking services (booking.com).

Tab. 1. Tourism websites for the biggest Polish cities

\begin{tabular}{|c|c|c|}
\hline City & Website & Characteristics \\
\hline \multirow{4}{*}{ Warsaw } & um.warszawa.pl & Website of the municipal office \\
\hline & warsawtour.pl ${ }^{8}$ & Travel website \\
\hline & wcit.waw.pl & Tourist information on a commercial website \\
\hline & informacja-warszawa.pl & $\begin{array}{l}\text { Tourist information on the website of the Pastoral } \\
\text { Center of the Archdiocese of Warsaw }\end{array}$ \\
\hline \multirow{4}{*}{ Krakow } & krakow.pl & Website of the city council (Magiczny Kraków) \\
\hline & krakow.travel & Travel website \\
\hline & 2krakow.pl & Tourist information \\
\hline & infokrakow.pl & Tourist information on a commercial website \\
\hline \multirow{2}{*}{ Lodz } & uml.lodz.pl & Website of municipal office \\
\hline & travel.uml.lodz.pl & Tourism subdomain \\
\hline \multirow{3}{*}{ Wroclaw } & wroclaw.pl & Website of municipal office \\
\hline & wroclaw-info.pl & Travel website \\
\hline & visitwroclaw.eu & Official tourism website \\
\hline \multirow{3}{*}{ Poznan } & poznan.pl & Website of municipal office \\
\hline & poznan.travel.pl & Travel website \\
\hline & plot.poznan.pl & Website of Poznan Local Tourist Organization \\
\hline \multirow{3}{*}{ Gdansk } & Gdansk & Website of municipal office \\
\hline & visitgdansk.com & Tourist information \\
\hline & trojmiasto.pl & Information service \\
\hline
\end{tabular}

${ }^{5}$ The domains have the following form: e-(city name).com. A recent iteration of the website describing one-time and cyclical cultural events called Local Life: local-life.com

${ }^{6}$ See: https://www.inyourpocket.com/poland. This international series, created by a company established in Krakow, was initially issued in the form of free or low-paid booklets distributed through a network of tourist information centers. Currently, the reader can use the information directly on the site, download a brochure in PDF format and install the application on the smartphone.

7 The company is based in Göteborg, Sweden. The system requires an e-mail address to which a personalized city guide is sent. Any information about a particular destination can also be accessed directly on the page.

${ }^{8}$ The URLs in bold are official city tourist information sites, which are subjected to detailed analysis later in the article. 
The analyzed website offer a mobile version in addition to the standard version displayed on personal computers. The modifications mainly concern the layout of the content which must be adapted to other screen parameters. There are a few exceptions to this rule, e.g. in the case of um.warszawa.pl (unadjusted format) or Wrocław-info.pl (unadjusted font size). The Trojmiasto.pl website has its own mobile version.

\section{Languages, translations}

The tourism websites of the largest Polish cities are characterized by a complex structure and intention to serve various promotional purposes. To a large extent, they are designed with international tourism in mind. It is worth noting that the websites are available in several languages (Tab. 2).

Tab. 2. Language versions of the tourist websites of Polish cities

\begin{tabular}{|l|l|}
\hline \multicolumn{1}{|c|}{ City } & \multicolumn{1}{c|}{ Language versions } \\
\hline Warsaw & Polish, English, German, Spanish \\
\hline Krakow & Polish, English, German, French, Spanish, Italian, Russian \\
\hline Lodz & Polish, English, German, French, Russian \\
\hline Wroclaw & Polish, English, German, Spanish \\
\hline Poznan & Polish, English, German \\
\hline Gdansk & Polish, English, German, Swedish, Russian \\
\hline
\end{tabular}

The Polish basic text is accompanied by similar resources across all sites translated into English and German, and in individual cases, additional foreign languages. The selection of languages was determined by the intensity of tourist traffic and the nationality of foreign tourists (e.g. in the case of Gdansk's website, Swedish and Russian, and in the case of Krakow, seven languages including Italian). The most extensive version is offered in the native language, while others are often limited while retaining the core, most relevant information.

\section{Website structure, navigation and hypertext links}

The internal structure of the websites is expressed in networks of links to specific content. The implementation of this scheme varies between individual sites, which is reflected e.g. by the varied number of links in the menu on the page (Tab. 3).

It should be noted structure of the site menu may vary and contain much more complex hierarchical submenus (as in the case of Krakow and Lodz). The Krakow and Poznan websites have two separate navigation systems. Warsaw's and Wroclaw's sites have drop down menus with lists of subcategories. It is relatively easy to identify different categories. They are divided into groups related to exploring the city and the associated services. The designers do not always take into account the separation of the top categories. There is a certain ambiguity in this regard, e.g. on the Krakow website, as the titles of various categories, "Tourist Guide" and "Excursions", or "Events" and "News" do not make clear 
why and how the content is divided between such two categories. The home page of Lodz distinguishes between traditional tourism and conventional tourism, where the content is partially duplicated (e.g. information on accommodation). Labeling shows the emphasis placed on items on the website. Certain elements are thus highlighted. The travel websites of Wroclaw and Gdansk have separate headings, for example, to describe the benefits of using the city tourist card, while on the websites of other cities such content is hidden deep within the structure of the web page.

Tab. 3. Content of the Polish cities' travel websites

\begin{tabular}{|c|c|c|}
\hline City & Main categories & $\begin{array}{l}\text { The total } \\
\text { number of items } \\
\text { in navigation }\end{array}$ \\
\hline Wroclaw & $\begin{array}{l}\text { Walking around in Wroclaw (Map); See Wroclaw; Land- } \\
\text { marks in Wroclaw; Events in Wroclaw; Weather in Wroclaw; } \\
\text { Exchange rates }\end{array}$ & 38 \\
\hline Lodz & Tourism; Convention; Organization; News & 29 \\
\hline Warsaw & $\begin{array}{l}\text { Welcome to Warsaw; top 10; What? Where? When?; Warsaw } \\
\text { Quest; See Warsaw in 1, } 2 \text { or } 3 \text { days; Overtime; Plan your stay }\end{array}$ & 26 \\
\hline Krakow & $\begin{array}{l}\text { Touch of history; Tourist guide; Plan your stay; Practical in- } \\
\text { formation; Recommended events; City map; What's new? }\end{array}$ & 24 \\
\hline Poznan & $\begin{array}{l}\text { Spring in Poznan (News); Poznan Tourist Card; Audio guides; } \\
\text { Top 10; Poznan area; Shopping in Poznan; Free Internet }\end{array}$ & 13 \\
\hline Gdansk & $\begin{array}{l}\text { Events; Shopping in Gdansk; Practical advice; Spa wellness } \\
\text { center with a tourist card; Calendar of events; Where to stay; } \\
\text { Where to eat; Gdansk Convention }\end{array}$ & 8 \\
\hline
\end{tabular}

Another important feature are hypertext links to different types of websites and services. All the studied websites have social media profiles, on Facebook, Twitter, and Instagram. Additionally, the Lodz travel website provides a link to its YouTube channel, showing short films presenting selected hotels, attractions and bird's eye views of the city. Additionally, some websites refer to other resources on related subjects or cooperating institutions ${ }^{9}$. For example, Krakow's site provides a link to the abovementioned website of the municipal office and to infokrakow.pl which is an online gift shop. The website also links the pages of the Krakow Festival Office, the ICE Congress Center, the Balice airport and thematic websites devoted to, e.g., children's programs and the literary life of the city. This offer will complement tourist-directed content. In addition to the links available directly on the main page, addresses of various cultural institutions presented in the description of the attractions, as well as restaurants, cafes, entertainment and accommodation facilities are often provided. Many links are hidden deeper ${ }^{10}$.

\footnotetext{
${ }^{9}$ In the case of Lodz, they are: Polish Tourist Organization (Polish Congress Office), the Convention Bureau of Poland, the International ICCA Association of Conferences and Congresses, the Ministry of Tourism and Sport, and the Institute of Urban Geography and Tourism, on top of the University of Lodz.

${ }^{10}$ For example, a link to the Institute of Urban Culture in Gdansk appears on the screens describing alternative attractions of the city as an invitation for trips organized by this institution. See: https://visitgdansk.com/corobic/dolne-miasto,a,13,3
} 
The website design and architecture put emphasis on its the promotional function. The travel websites usually organize their content differently from the municipal websites. The menu, placed on the top or on the side of the page, may include panoramic photographs, advertising film clips, animated gifs or sequences of pictures. This type of presentation renders the website more similar to a blog. It also alerts the user to the most interesting places and presents content in a more dynamic way. The homepage acts as an extensive cover containing links to most of the main content and is the city's showcase at the same time. For example, on the Warsaw website, the list opens with an advertisement signed as Welcome to Warsaw followed by a shifting bar with photographs presenting the top 10 attractions of the city, and a banner advertising cultural events, entitled What? Where? When?, a list of suggested sightseeing routes marked with appropriate symbols for exploring the city in 1, 2 or 3 days, followed by other practical information on eating out, shopping, transportation, etc. (Tab. 3). The individual contents are also available from the main navigation. There is of course an extensive system of references to navigate the website. It is worth noting that within each section, the user can choose and select content, and a promoted item is highlighted by a corresponding animation. Such a system is quite different from more traditional websites, such as, for example, that of the Warsaw city office (um. warszawa.pl), where there is a clear division between the global, local and contextual navigation. Krakow's largest travel website is maintained in a similar way, but it features a map with a set of tags and a media planner allowing tourists to create a program of their visit depending on declared preferences (relaxing or sightseeing, specific date, hours of the tour, mode of transportation, inclusion of children's attractions). Since this type of 'swipe-able' page is only partially visible from the homepage, the layout of the content is important, as is the placement of its visible part performing the function of a "cover". Krakow's website presents a photograph of a large portion of the Market Square with iconic elements of the Marian Church Towers and a decorated horse carriage.

\section{Games and cultural context}

A specific part of the presentation of the cultural offer of Poznan are urban games based on role-playing and mystery-solving in a particular area involving finding local landmarks and learning the city's history. Tasks of this type generally require the use of modern methods of geolocation. The capital of Greater Poland is one of the national leaders when it comes to this strategy of self-promotion. Here, Poland's first tramway game was created, and the system of this type of competition was promoted at the International Tourism Fair in Berlin (Smoleńska, 2009). The Poznan website provides several card for download before starting the game, which can be a way to explore city or its surrounding area in an unusual way ${ }^{11}$. Additionally, it contains a form allowing the user to register and save game statistics regarding the solving of the mystery (the solution has been borrowed from computer games involving setting new records).

Another original feature is a survey exploring tourists' preferences and allowing to propose individual sightseeing programs. In case of the capital, Warsaw Quest divides tourists

${ }^{11}$ See: http://poznan.travel/pl/r/gry-miejskie/miejskie-gry-turystyczne 
into four categories formed on the basis of the capital's most famous legends: the Warsaw Mermaid, Wars and Sawa, the Golden Duck, and the Basilisk ${ }^{12}$. Thus, convention 'infotainment' is used here. Of course, the materials on the website reflect the specific culture and history of a given city. Thence, for example, on the site of Lodz, the content dedicated to the industrial heritage of the city (the Empire of K. Scheibler, the Empire of I. Poznanski, the Empire of L. Geyer), the Litzmannstadt's Ghetto, and the film-making heritage. Wroclaw's website contains a large section describing the local dwarf statues, and the seaside city of Gdansk - a description of the local beaches, and so on.

\section{Maps and walk routes}

Interactive maps are an important element of the websites' content. They appear at different levels of the websites and enable direct location of the place described, e.g. a monument, place of accommodation, a place to eat or an entertainment facility (Kalecińska, 2013). Cartographic representation is also used for marking the routes of suggested walks around the cities. Usually, interesting objects are marked on the maps, but the route itself is marked as well ${ }^{13}$. The websites usually use the cartographic background of Google Maps, while the Wroclaw website used the Open Street Map. The map of Lodz murals has an original map as a background ${ }^{14}$.

Tab. 4. The number of proposals for urban routes on the websites of the largest Polish cities

\begin{tabular}{|c|c|}
\hline City & Number of tours \\
\hline Wroclaw & 30 \\
\hline Gdansk & 18 \\
\hline Krakow & 17 \\
\hline Warsaw & 12 \\
\hline Lodz & 12 \\
\hline Poznan & 8 \\
\hline
\end{tabular}

City walk routes are an important component of each of the analyzed sites (Tab. 4). The routes are thematic (e.g. Gothic Gdansk) or zonal (directing the visitors within one district or quarter, for example the Wroclaw Nadodrze). This type of content is much less frequent on the websites of smaller cities, because of a smaller number of attractions. Such proposals make it easy to explore the city, especially because in addition to the descriptions they provide information on the approximate duration of the individual city walks. In the case of Wroclaw, individual routes were suggested by residents ${ }^{15}$. Similarly, Green Krakow program was established in cooperation with the city greenery infrastructure. It is worth noting that Krakow's green areas have recently undergone a complete revitalization, which

\footnotetext{
12 http://warsawquest.warsawtour.pl/

${ }^{13} \mathrm{http}: / /$ footsteps.city/trasy/trasa/?title=Wroc\%C5\%82awskie\% 20Nadodrze \& id = 0RzNXJWl5B

14 https://lodz.travel/turystyka/co-zobaczyc/murale/

15 https://visitwroclaw.eu/o-serwisie
} 
was related to a number of additional initiatives such as the rise of small "pocket" parks, a number of local initiatives involving the organization of new green areas, line parks along roads and flower meadows (Kempf, 2017).

\section{Graphic and verbal identification and promotion of cities}

Graphical signs often accompanied by a promotional slogan are an important element of the identification of the tourist destination. In the case of Warsaw, the page shows a stylized form of the Warsaw Siren and the English-language slogan "Fall in love with Warsaw". The symbol of the tourist information in Krakow is a more sophisticated sign reminiscent of a peacock feather worn on the regional "krakuska" hat. A more recognizable symbol of Krakow, however, is the sign resembling the letter " $K$ " showing the layout of streets adjacent to the Market Square. The krakow.travel.pl site also includes the slogan "Touch history". Similar logos can also be found on other sites analyzed. Lodz has a logo composed of the four letters of the city's name styled as a gear system typically associated with the technical and industrial heritage of Lodz, inscribed in a square. Wroclaw and Poznan are distinguished by special lettering, while the symbol of Gdansk in addition to the thumbnail of the historical coat of arms of the city is an origami duck or a boat.

Prizes won by the cities in competitions at national or international levels also seem to be another important element. Appropriate European Best Destinations vignettes are placed on the travel sites of Wroclaw, Poznan and Gdansk, while Lodz advertises itself as one of the organizers of the FIFA World Cup U-20 in 2019. The Best in Travel tab describes other activities in the tourism industry of Lodz, including participation in the Lonely Planet poll in 2019.

\section{Additional materials to make sightseeing more attractive}

Digital material of various kinds intended for printing or using while sightseeing is an important part of the offer (Tab. 5).

Tab. 5. Digital versions of brochures and mobile applications available on the tourism websites

\begin{tabular}{|c|c|c|}
\hline City & Number of brochures & Number of mobile applications \\
\hline Warsaw & 9 & 11 \\
\hline Krakow & $1^{16}$ & $8^{17}$ \\
\hline Lodz & 6 & - \\
\hline Wroclaw & 1 & 2 \\
\hline Poznan & $31^{18}$ & 11 \\
\hline Gdansk & 5 & 4 \\
\hline
\end{tabular}

16 Excerpt of the Kids In Cracow guide in JPG files.

17 The website contains only a description of the application, which can be downloaded from an online store.

18 The number of separate titles - most of them is available in several languages. 
In the past, a variety of brochures, guides and maps was provided as files in PDF format, less frequently in text formats (DOC, TXT) or graphic ones (JPG). Today, they are often available in the form of multifunctional mobile applications allowing access to interactive content via a smartphone with a GPS module. They facilitate orientation in the city and the finding of a variety of interesting objects, for example, Go Wroclaw Krasnale allows the user to reach all 334 dwarf statues scattered around the city ${ }^{19}$. Some of these applications are designed for specific types of visitors, for example, for disabled people or for children. Thanks to a relatively high-capacity digital format, they have effectively replaced thick guide books (e.g. Footsteps application comprises several tens of routes around Wroclaw with detailed descriptions of individual sightseeing spots). Others rely on smartphones' capacities to handle multimedia, for example, the Warsaw Selfie $z$ Chopinem (Selfie with Chopin) enables the user to post personalized pictures of emblematic spots in the capital associated with the most famous Polish composer, while Krakow's Graj Hejnat (Play Heynal) allows the user to play the best known melody in Poland. These applications are available in online stores (usually for free), the websites usually containing only links leading there. These applications are subject to fast verification based on user feedback. Such opinions, however, are found only on the websites of online stores and it is not possible to review the products on the tourist sites. It must also be noted that the described websites do not facilitate extensive interaction. The possibility of leaving comments was transferred to social media accounts associated with the websites.

\section{Conclusions}

The analyzed websites are different from each other, despite the fact that they were all designed for related organizational entities gathered in the structure of Polish Tourism Organization. Each website has a different architecture and design. It seems that they are more varied than for example the websites of the analogous organizations operating in countries such as Germany, the Netherlands, and Sweden. The specificity of the region has more of an impact on the content offered to the user. All cities, especially large ones, are characterized by high vitality and diversity (Proszowska-Sala \& Florek, 2010, 20-21), therefore their promotion must take into account many different aspects of their functioning. This, among others, was caused by the recent transformation of these websites, to make them more attractive with the use of e.g. large format graphics and a variety of multimedia features. This trend is noticeable on the website of big cities across all of Western Europe. The website are becoming more like personal blogs, which is a visible symptom of more frequent updating, the introduction of the category of news, copyright texts and various trivia. The importance of non-verbal content, such as films, photographs, multimedia presentations is also rising. This is evidenced also by the slow replacement of printed publications with mobile applications. The "infotainment practices" further the transition from the paradigm of regional education in the direction of regional marketing.

19 The application is unfortunately quite outdated and does not include new statues, which appear in various places of the capital of Lower Silesia. 
The branding of large cities depends not only on providing the visitors with up-to-date information, but also stressing the identity of the place so it would compel more than one visit. Therefore, various websites devote increasing space to advertising particular tourist products.

\title{
References
}

Goworecki, W. (2003). Turystyka, Warszawa: Polskie Wydawnictwo Ekonomiczne.

Kalecińska, J. (2013). Nowe technologie w branży turystycznej [online]. Warszawa: AWF. [04.12.2019], http://docplayer.pl/439358-Nowe-technologie-w-branzy-turystycznej.html

Kempf, P. (2017). Zielony wymiar miejskiego szczęścia. In: H. Mazur (ed.). Miasto na plus. Eseje o polskich przestrzeniach miejskich (93-113). Kraków: Wysoki Zamek.

Kęprowska, U. (2012). Promocja produktu turystycznego na przykładzie Gdańska. Zarzadzanie $i$ Finanse, 2, 73-89.

Kruczek, Z., Walas, B. (2004). Promocja i informacja turystyczna. Kraków: Proksenia.

Meyer, B., Pawlicz, J. (2010). Informacja w turystyce. In: A. Panasiuk (ed.). Informacja turystyczna. Warszawa: Wydaw. C.H. Beck.

Ostrowska, B. (2010). Ocena funkcji turystycznej miast wojewódzkich w Polsce. Zeszyty Naukowe Uniwersytetu Ekonomicznego w Krakowie, 842, 53-67.

Paliś, B. (2017). Miejsce turystyki zakupowej w strategiach miast w Polsce i na świecie. Marketing $i$ Zarzadzanie, 1, 39-49.

Proszowska-Sala, A., Florek M. (2010). Promocja miast. Nowa perspektywa. Warszawa: Ströer Polska. Reformat, B. (2015). E-turystyka i uwarunkowania jej rozwoju w Polsce - wybrane aspekty analizy. Zeszyty Naukowe Uniwersytetu Ekonomicznego w Katowicach, 215, 74-89.

Smoleńska, O. (2009). Najnowsze trendy w turystyce eventowej: gry fabularne i wydarzenia związane z fantastyką i technologią XXI wieku. Turystyka Kulturowa, 8, 31-39.

\section{Internetowe formy informacji turystycznej największych miast Polski}

\begin{abstract}
Abstrakt
Cel/Teza: Przedmiotem artykułu są wybrane internetowe serwisy informacji turystycznej dla sześciu miast Polski. W artykule poszukiwano odpowiedzi na następujące problemy badawcze: czy strony internetowe poświęcone informacjom turystycznym na temat poszczególnych miast mają zestandaryzowaną konstrukcję?; czy lokalne warunki wpływają na charakter treści pojawiających się na stronach internetowych poświęconych turystyce miejskiej oraz formę ich prezentacji?; czy interesujące nas strony są wielojęzyczne?; czy serwisy te sugerują jakieś trasy zwiedzania?; jaki był kierunek ich ewolucji?

Koncepcja/Metody badań: Posługując się metodami analizy porównawczej, statystyki oraz krytycznego opisu, porównano systemy elektronicznej informacji turystycznej największych miast Polski: Warszawy, Krakowa, Łodzi, Wrocławia, Poznania i Gdańska. Ośrodki te w większym lub mniejszym stopniu istnieją w świadomości społecznej jako potencjalne cele turystyczne - każdy z nich ma odrębny system informacji odzwierciedlający po części lokalne różnice w rozwoju rozpatrywanego sektora usług. Internetowa przestrzeń informacyjna odpowiada złożonemu charakterowi tej dziedziny aktywności gospodarczej, z którą związane są podmioty o rozmaitej randze i proweniencji.
\end{abstract}


Wyniki i wnioski: Przeanalizowane serwisy turystyczne charakteryzują się wysokim stopniem zindywidualizowania, mimo że pochodzą z powiązanych jednostek organizacyjnych zebranych w Polskiej Organizacji Turystycznej. Każda witryna to inny projekt pod względem zasobów, projektu, grafiki i szczegółowych rozwiązań, które składają się na architekturę informacji. Pod tym względem rozpatrywane centra informacji turystycznej są znacznie bardziej zróżnicowane niż podobne serwisy działające np. w: Niemczech, Holandii i Szwecji. Specyfika lokalna ma bardzo duży wpływ na treści pojawiające się na stronach internetowych poświęconych turystyce miejskiej. W ostatnich latach widoczna jest ewolucja pierwotnie statycznych witryn WWW stanowiących ekwiwalent papierowych przewodników w kierunku multimedialnych platform umożliwiających rozmaite interakcje i prezentujących bardziej zdynamizowane treści. Ważnym elementem dzisiejszej oferty informacyjnej stają się aplikacje multimedialne ułatwiające wszechstronną aktywność turystyczną stanowiące też niekiedy wyraz inicjatywy w kreowaniu konkretnego produktu turystycznego.

Oryginalność/Wartość: Zgodnie z wiedzą autora, artykuł jest pierwszą próbą charakterystyki i porównania internetowych serwisów informacji turystycznej sześciu największych miast Polski.

\section{Słowa kluczowe}

Analiza porównawcza. Informacja turystyczna. Struktura stron internetowych. Zawartość stron internetowych.

Dr hab. MICHA£ ROGOŻ is a professor of the Pedagogical University of National Education Commission in Krakow and the director of its Institute of Information Sciences. He is the thematic editor of "Annales Universitatis Paedagogicae Cracoviensis. Studia ad Bibliothecarum Scientiam Pertinentia" and a secretary of "Yearbook of the History of the Polish Press". He is a member of the Polish Librarians' Association and the local coordinator of the International Society for Knowledge Organization. His research interests encompass children's media, issues in tourism considered through the lens of library and information science, censorship, and protection of intellectual property in digital environment. He published over 100 texts, among them several books: Czasopisma dla dzieci i młodzieży Instytutu Wydawniczego „Nasza Księgarnia” w latach 1945-1989 (Kraków, 2009), Fantastycznie obecne. Anglojęzyczne bestsellerowe cykle powieściowe dla dzieci i mtodzieży we wspótczesnej polskiej przestrzeni medialnej (Kraków 2015), Prasa dla dzieci i młodzieży 1824-1918, t. 1-3, Kraków 2018 (co-author).

Contact to the Author michal.rogoz@up.krakow.pl

Instytut Nauk o Informacji

Uniwersytet Pedagogiczny im. Komisji Edukacji Narodowej w Krakowie

ul. Podchorażych 2

30-084 Kraków 